\title{
La imagen en primer plano: La pasión de Juana de Arco y el poder del rostro
}

Cristina Alayza Prager

Pontificia Universidad Católica del Perú

Resumen: Dos particularidades de la película La pasión de Juana de Arco (Carl Theodor Dreyer, 1928) son exploradas en este ensayo: sus insólitos primeros planos y su carácter fuertemente expresivo. Partimos de la idea de que ambas características están íntimamente relacionadas y buscamos esclarecer esta relación sirviéndonos de la imagen-afección de Gilles Deleuzey de la imagen dialéctica de Georges Didi-Huberman.

Palabras clave: rostro, imagen, primer plano, afección, movimiento

Abstract: Two peculiarities of the film The Passion of Joan of Arc (Carl Theodor Dreyer, 1928) are explored in this essay: its unusual close-ups and its strongly expressive character. We start from the idea that both characteristics are closely related and we seek to clarify this relationship making use of Gilles Deleuze's affection-image and Georges Didi-Huberman's dialectical image.

Key words: face, image, close-up, affection, movement 


\section{$\S 1$. Encuadre}

“¿Cómo mostrar un vacío? ¿Y cómo hacer de este acto una forma -una forma que nos mira?"

Georges Didi-Huberman

La película se inicia con el interrogatorio de Juana de Arco. No han pasado muchos minutos $y$, sin embargo, la impresión que ha dejado en nosotros Carl Theodor Dreyer es notable. Tampoco podemos decir que haya habido un avance considerable en el curso de la acción de la película; a Juana de Arco, que está siendo juzgada por herejía (por creerse enviada de Dios para salvar a Francia), se le ha preguntado simplemente si conoce el Padrenuestro y quién se lo enseñó, a lo que ella responde que su madre. No obstante, hemos sido introducidos y conmovidos por el conflicto de Juana de Arco. Se ha generado, por decirlo de algún modo, una suerte de vínculo afectivo, sumamente íntimo, con el personaje de Juana de Arco. Hemos sido afectados, perturbados por ella. Por más que sepamos de antemano la trágica suerte que correrá esta muchacha en el transcurso del proceso, no podemos ahora hacer otra cosa que acompañarla a lo largo de sus pesares y tormentos; sufrir con ella. Más aun: por más que sepamos de antemano la suerte que correrá Juana de Arco y podamos, por ello, anticiparnos y protegernos de la tragedia que sufrirá la muchacha, esa anticipación no nos libra de la inquietud a la que nos conduce la imagen del rostro de Juana de Arco. Este es el tema que abordará el presente ensayo.

Mi interés por La pasión de Juana de Arco no es ni arcaico ni melancólico. No pretendo hacer una disertación sobre la relevancia para la historia del cine de una película que, desde hace ya mucho tiempo, ha pasado a engrosar las filas de los clásicos del cine (y no solo del mudo). Tampoco pretendo reflexionar, a partir de la tragedia de Juana de Arco, sobre los conflictos, tormentos y sufrimientos del género humano. Mi interés en esta película tiene que ver con un tema específico y menos ambicioso que los anteriores, que consiste en el poder de la imagen, $y$ en este caso particular, en el poder de la imagen en primer plano. Como he tratado de mostrar, las imágenes que nos ofrece Dreyer del rostro de Juana de Arco (y no solo de ella) no son "simples" imágenes. Son imágenes que poseen una fuerza especial, capaces de retenernos, de sacudirnos. Puede no estar pasando nada en ellas (hay, detrás de ellas, una 
simple pregunta, ni siquiera una pregunta muy importante para los efectos del proceso; vemos simplemente una mirada, una lágrima, el temblor de los labios... nada, quizá, digno de una atenta consideración), y sin embargo estas imágenes dejan un poderoso rastro en nosotros difícil de disipar. Sobre este "poderoso rastro" de las imágenes del rostro de Juana de Arco en primer plano quisiera hacer unas breves reflexiones en este escrito, con el interés de esclarecer su inquietante condición'.

\section{§ 2. Guión y reparto}

Habitualmente entendemos el primer plano como una toma cinematográfica que recoge el rostro y los hombros con una distancia íntima, y que sirve para mostrar confidencia e intimidad respecto al personaje. Hay distintas variantes del primer plano (plano detalle, primerísimo primer plano, etc.), pero todas, supuestamente, dotarían de gran significado a la imagen ${ }^{2}$.

La pasión de Juana de Arco recurre constantemente al primer plano, y no solo para mostrar el rostro de Juana, sino también de distintos personajes e, incluso, para mostrar objetos. Recordemos las imágenes de los objetos de tortura. Y es que, claro, hacer una toma desde una distancia íntima no tiene porqué restringirse exclusivamente al rostro. No obstante, hay un elemento casi obsesivo en los primeros planos de Dreyer que parece hacer desfasar su concepción del primer plano respecto del modo habitual en que solemos entenderlo. Es un recurso bastante simple, y sin embargo puede resultar hasta perturbador. Me refiero a la persistencia de Dreyer de no mostrarnos el rostro completo ${ }^{3}$. Este podría ser un primer indicador de cómo cada director hace suyos los elementos y las herramientas cinematográficas. Ya lo decía Deleuze: los directores son también grandes pensadores, ellos "piensan con

I Tomo el término de Didi-Huberman: "Dar a ver es siempre inquietar el ver" (DidiHuberman, Georges, Lo que vemos, lo que nos mira, traducción de Horacio Pons, Buenos Aires: Manantial, 1997, p. 47; cf. ibid., p. 17).

2 Definiciones tomadas deWikipedia(http://es.wikipedia.org/wiki/Plano_cinematografico).

3 Gilles Deleuze llama a este procedimiento primeros planos fragmentados (cf. Deleuze, Gilles, La imagen-movimiento. Estudios sobre cine I, traducción de Irene Agoff, Barcelona: Paidós, 1984, p. 157). 
imágenes-movimiento y con imágenes-tiempo, en lugar de conceptos”4. En ese "pensar con imágenes", el director hace algo con la materia cinematográfica y nos induce a nosotros a penetrar en esa materia. No es un error de la toma, ni un error de la percepción el que los primeros planos en Dreyer aparezcan desfigurados. La dimensión que Dreyer abre para nosotros se mueve de esa manera. Así, no queda más que admitir que las definiciones tradicionales de primer plano son insuficientes para reflexionar sobre la potencia del rostro de Juana de Arco en esta película.

En un texto de 1933, el propio Dreyer aludía a La pasión de Juana de Arco de la siguiente manera: "Lo que los extraños primeros planos le comunican al espectador, que tal vez se sintiera cautivado por ellos, no fue elaborado al azar. Todas esas imágenes expresan el carácter de la persona que las muestra y el espíritu mismo de los tiempos. Sacrifiqué los 'embellecimientos' respecto a la verdad"5. Las imágenes de Juana de Arco fueron elaboradas así, desfiguradas, intencionalmente. Y esto le permitió a Dreyer expresar con más autenticidad aquello que quería expresar: sacrificó los embellecimientos respecto de la verdad. Este rechazo a los embellecimientos se desprende de la relación conflictiva que Dreyer mantuvo con el teatro. El teatro necesita de ellos porque tiene que hacer exageradamente visibles los gestos de los actores para que puedan llegar hasta la última fila de butacas. Es decir, en el teatro no hay primer plano. El actor representa un papel, y esa representación tiene que pasar por el disfraz, la máscara, la exageración ${ }^{6}$. No ocurre lo mismo

4 Ibid., p. 12.

5 La cita continúa así: "Sacrifiqué los 'embellecimientos' respecto de la verdad. Mis actores no debían acercarse siquiera al colorete y a las borlas del maquillaje en polvo" (Dreyer, Carl Theodor, Reflexiones sobre mi oficio. Escritos y entrevistas, traducción de Nuria Pujol i Valls, Barcelona: Paidós, 1999, p. 40, cursivas añadidas). Esta cita figura en un pequeño texto titulado "La mística realizada", que apareció en el diario Politiken el día 19 de noviembre de 1933.

6 "La distancia que el teatro inspira a Dreyer cristaliza en el rostro del actor. Palabras como 'colorete', 'polvos', aparecen frecuentemente en los Escritos, con una mueca de disgusto. El horror casi fóbico que Dreyer alimenta con relación a todo lo que es maquillaje del actor, los polvos, el colorete, las pelucas, los postizos sólo tiene parangón en la pasión wellesiana por utilizarlos: capas y más capas, máscaras, disfraces. El movimiento es simétrico aunque la diferencia, vista con relación al teatro, no es tanta. La variedad de angulaciones de Juana de Arco, sus primerísimos planos, no tienen nada que envidiar a las aberraciones wellesianas. Para Dreyer, insistió en ello en multitud de ocasiones, el rostro del actor es el todo del cine. (...) para la cámara es tanto un cuadro (una superficie, un paisaje) como un escondite: su desnudez extrema, bajo la torsión del ángulo de la toma, duplica por la vuelta de tuerca suplicante del cuadro, tropieza definitivamente con el tope infranqueable de la película y la piel” (Charles Tesson, "Los suplicios del teatro", en: Dreyer, Carl Theodor, op. cit., pp. 21-22). 
en el cine. Según Dreyer, la imagen cinematográfica está, de alguna manera, más cerca de la verdad que de su representación: está más cerca del carácter de la persona, está más cerca del espíritu de los tiempos. Nos permite una expresión más auténtica, que no necesita de "embellecimientos" exteriores. $Y$ esto ciertamente tiene que ver con el procedimiento del primer plano: "En un plano general, el actor tenía que gesticular y utilizar todos sus recursos de gran mimo. En el primer plano, que pone de manifiesto hasta el menor gesto, los actores tenían que actuar de un modo natural y auténtico. El tiempo de las muecas había pasado. El cine había encontrado el camino de la representación del hombre"7. El primer plano habría dado la oportunidad de captar en imágenes algo bastante más profundo. Las imágenes de La pasión de Juana de Arco fueron construidas con esa intensión.

Evidentemente, el avance de la técnica cinematográfica y, en concreto, el desarrollo de la técnica del primer plano, permitió este avance respecto del teatro, tal como acaba de señalarnos Dreyer. Sin embargo, evidentemente también, la técnica no puede explicarnos por sí sola esta introducción en la interioridad. Ya Walter Benjamin, en uno de sus escritos más famosos, nos lo ha demostrado: la técnica pertenece al orden de la reproducción, opera cuantitativamente. Un salto cualitativo semejante no se explica entonces, exclusivamente, por vía técnica. Dreyer también se pronunció al respecto: "Podría creerse que, con todas estas cualidades, el cine (...) había alcanzado la perfección, y sin embargo (...) ino le faltaba algo? Todo era tan auténtico, tan creíble, tan verosímil (...). Y, no obstante, no nos lo creíamos. Nos sentíamos siempre interesados, a menudo sorprendidos, muy raramente cautivados. Un demonio nos soplaba al oído: ise trata meramente de una cuestión de técnica? Lo que le faltaba era el alma" ${ }^{8}$. El alma le corresponde darla al director. La técnica cinematográfica no consigue auténticas imágenes si es que ella no pasa por la elaboración propia del director, que, como decíamos, hace suyas las herramientas que el cine le ofrece para darnos, por decirlo de algún modo, una perspectiva, para abrirnos una nueva dimensión. La técnica puede reproducir fiel y masivamente, pero ella sola no contribuye con la generación del alma. Imagen

$7 \quad$ Ibid., p. 28. La cita corresponde a un texto publicado por Dreyer en otro diario, el Dagbladet, el 7 de enero de 1920.

8 lbid., p. 29. 
no es, pues, sinónimo de reproducción?. Imagen es algo más. De ahí, pues, que podamos concluir con Dreyer que "no sólo cuenta la técnica. También cuenta el hombre. Está en su poder crear atmósferas que nos persuadan de la verdad de lo que está ocurriendo en la pantalla. Puede favorecer las intenciones del director, o puede obstaculizarlas. Si tiene un verdadero sentido del juego de la luz y las sombras, puede, con sus iluminaciones, crear ritmos luminosos que estén en consonancia con los demás elementos de la película y contribuya así al ritmo global de la obra; lo que el público percibe sin tener conciencia de su origen"10.

Quisiera detenerme en esta última frase: "lo que el público percibe sin tener conciencia de su origen". Nos adentramos en la atmósfera de Juana de Arco, somos afectados por ella, sin tener conciencia del origen de esta afección. ¿Cómo así lo logra Dreyer? Por lo pronto, sabemos ya dos cosas. Primero, sabemos de manera general, como acabamos de ver, que esta afección no se explica apelando solo a la técnica. Segundo, de manera más concreta, sabemos también que los primeros planos de Dreyer, como veíamos al inicio, no se explican recurriendo a nuestro modo habitual de entender un primer plano, pues Dreyer insiste en no mostrar el rostro completo. Y esto, más que obstaculizar nuestro enganche con el film, dota a estas imágenes de un poder especial. Ocurre sin que tengamos conciencia de su origen.

Lo que quiero sostener en esta presentación es que, en general, el cine nos permite contemplar las cosas de una manera que escapa a nuestra percepción habitual de ellas. En particular, me interesa ver esto a la luz de los primeros planos de Dreyer, puesto que en este caso nos vemos forzados a preguntarnos por la desfiguración de las imágenes. Gilles Deleuze y Georges Didi-Huberman nos dan elementos para pensar en profundidad este tema. El camino que voy a seguir a continuación es negativo: intentaré mostrar, primero, cómo no debe abordarse el tema de la imagen en primer plano. De ahí extraeremos las conclusiones que nos permitan elaborar en positivo, al

9 Cf. Benjamin, Walter, La obra de arte en la época de su reproductibilidad técnica (1936), en: Discursos interrumpidos I, Madrid: Taurus, 1982, pp. 24-25.

10 Dreyer, Carl Theodor, op. cit., pp. 56-57, cursivas añadidas; texto aparecido originalmente en el diario B.T. el 12 de julio de 1939. 
final de esta presentación, el primer plano en Dreyer. Entremos, pues, de la mano de ambos autores, a mayores detalles.

\section{§ 3. Montaje y dirección}

Según Deleuze: (I) el primer plano no se define por sus características o determinaciones espaciales, sino por otra cosa: su capacidad para expresar el afecto. Esto lo logra, en tanto consigue abstraer el rostro de sus coordenadas espacio-temporales". De aquí que Deleuze concluya que "no hay primer plano del rostro. El primer plano no es sino el rostro, pero precisamente el rostro en tanto que ha anulado su triple función"'2: función individuante (distinguir a cada quien), socializante (manifestar un rol social) y relacional o comunicante (asegurar la comunicación). Esto se puede entender en más de un sentido; me interesa resaltar dos:

- El primer plano no se define por sus características espaciales en tanto objeto. Digamos: en el primer plano, no es simplemente que yo vea un objeto particular desde una distancia más cercana, sino que el objeto enfocado en primer plano ha sido abstraído de sus coordenadas espaciotemporales $y$, por tanto, no lo veo ya como una cosa (de ahí que pierda su función individuante).

- En segundo lugar, el primer plano no se define por sus características espaciales en tanto perteneciente a un estado de cosas. No lo veo más como un objeto encadenado a estado de cosas particular del cual dependa. El primer plano, nuevamente, ha sido abstraído también del estado de cosas al que pertenece originalmente (de ahí que pierda su función socializante y su función comunicante).

Entonces, si trabajamos el tema del primer plano a partir de sus coordenadas espaciales, como naturalmente nos vemos tentados a hacer, no estaremos atinando en explicar su capacidad para expresar el afecto. Fallaremos, entonces, en la consideración del primer plano.

II Cf. Deleuze, Gilles, op. cit., pp. 142, 154.

12 Ibid., p. 147. 
En un sentido, me parece, similar, Didi-Huberman sostiene que (2) una imagen no es inquietante de por sí; si una imagen nos inquieta, es porque está sostenida por un vacío, una pérdida. Podríamos decir: no toda imagen es una imagen inquietante (no todo rostro, enfocado desde una distancia íntima, es una imagen en primer plano). Si es inquietante, es porque hay algo en ella que se nos escapa, que nos elude. No obstante, hay dos procedimientos por los cuales uno puede evadirse de esta pérdida, no confrontarla; Didi-Huberman los llama la estrategia de la creencia y la estrategia de la tautología:

- La primera consiste en llenar el vacío con una suerte de sobresignificación: darle a lo visto (a la imagen) un sentido trascendente (teleológico o metafísico).

- La segunda consiste en llenar el vacío sosteniendo que no hay más de lo que se ve (podríamos decir: la mirada no va hacia adentro: se ve simplemente lo que se tiene enfrente).

La primera sobredimensiona el asunto; la segunda, se niega a ver más allá de lo que se ve. Ambos procedimientos, dice Didi-Huberman, son, en el fondo, formas de represión, arbitrarias y "chatas", que pretenden vencer a la mirada, escapar de la pérdida ${ }^{13}$. Ambos procedimientos, nuevamente, fallan en la consideración de la imagen.

Ambos procedimientos podrían emplearse en la interpretación de La pasión de Juana de Arco. Empecemos por la estrategia de la creencia. Podríamos vernos tentados a dotar al rostro de Juana de un sentido trascendente. La misma trama de la película, inclusive, parece sugerirlo: Juana sostiene una y otra vez que ella es "enviada de Dios"; al mismo tiempo, está siendo "injustamente" juzgada, es una víctima; nosotros, por nuestra parte, presenciamos su "martirio". La historia que Dreyer ha querido poner en imágenes ante nuestros ojos es una que se presta perfectamente para este tipo de estrategia: podríamos interpretar su historia como la expresión de una injusticia suprema, podríamos cuestionarnos en torno a las desgracias humanas. Pero todo esto es independiente de la imagen de su rostro en primer plano. Basta con recordar la historia de Juana de Arco, independientemente de cómo la narró Dreyer a

I3 Cf. Didi-Huberman, Georges, op. cit., capítulo 2: "La evitación del vacío: creencia o tautología”, pp. 19-26. 
través de imágenes, para atribuir todo este conjunto de connotaciones. Con esta estrategia, entonces, lo que hacemos es escabullirnos de la imagen misma. No hablamos de ella, sino que hablamos "alrededor" de ella. La evadimos.

Deleuze ya nos lo ha advertido: el primer plano ha abstraído el rostro de su enganche con un estado de $\operatorname{cosas}^{14}$. En el caso de Juana de Arco, hay un estado de cosas histórico que es por todos conocido (el proceso de Juana de Arco), pero hay algo más. Y este "algo más" no es lo suprahistórico o lo trascendente de la estrategia de la creencia, sino lo que Deleuze llama expresión del afecto. Extraigamos, pues, como lección, tanto de Didi-Huberman como de Deleuze, que no explicamos la potencia de las imágenes en primer plano del rostro de Juana basándonos en significaciones trascendentes o suprahistóricas. Anulemos, así, la estrategia de la creencia.

La segunda estrategia para evadirnos del vacío o la pérdida, la estrategia de la tautología, consiste en afirmar que solo vemos aquello que se ve, lo que se tiene enfrente, y nada más. Podríamos decir: solo vemos un rostro, nada más que un rostro. Tenemos, ante nosotros, la pura presencia del rostro de Juana, la especificidad, la amplificación de su rostro, vemos de cerca sus detalles, sin ningún otro propósito que mostrar el rostro tal cual es y nada más que él. La exigencia de esta estrategia es no ver más allá de lo que se ve: anular el juego de ilusiones $y$ asociaciones, el juego de sentidos y connotaciones al que se presta la imagen. No hay misterio detrás del rostro, la imagen en primer plano, según la tautología, mostraría al rostro tal como es, libre de equívocos, pero libre, asimismo, de significación. No abriría una nueva dimensión, precisamente aquella que nos ofrece Dreyer. La imagen buscaría exclusivamente la transparencia del objeto; el rostro no tendría nada que decirnos. Nada de interioridad. Nada que expresar. Hacer énfasis en el rostro mismo para no mostrar nada más que el rostro mismo.

Encontramos también elementos, en La pasión de Juana de Arco, que podrían llevarnos a suscribir una posición semejante. Alguien podría sostener que los primeros planos que Dreyer emplea con tanta asiduidad no tienen otra función que la de resaltar nada más que el detalle del rostro. Pero creo que basta con

I4 Cf. Deleuze, Gilles, op. cit., p. 156. 
volver a la escena descrita al inicio para dudar de esta interpretación: ciertamente, vemos con bastante detalle el rostro de Juana, pero no nos quedamos meramente en él. O mejor dicho: vemos la imagen insólita del rostro de Juana, pero no nos quedamos en el deletreo mudo de sus detalles, contornos, etc. Hay, como dijo Deleuze, "algo más"; el primer plano de Juana no nos atrapa por la configuración espacial de su rostro. La condición inquietante de estas imágenes no se explica por el deletreo mudo de los detalles del rostro. Nuevamente, tal como decía Deleuze, si el primer plano de Dreyer nos atrapa de esa manera es porque su rostro ha perdido sus coordenadas espaciales y ha perdido, así, su función individuante. La estrategia de la tautología debe ser, también, desechada.

Vemos, entonces, que lo que caracteriza al primer plano no es su dimensión espacial, su "geometría" o "fisonomía", sino su capacidad para expresar el afecto, como dijo Deleuze. Vemos, además, que el acontecimiento histórico no es suficiente, tampoco, para explicar esta capacidad expresiva de las imágenes de Dreyer. Deleuze nos dice ahora: "El primer plano no es una amplificación; si implica un cambio de dimensión, se trata de un cambio absoluto. Mutación del movimiento, que cesa de ser de traslación para volverse de expresión"15. El primer plano no amplifica, como si fuera un microscopio, nuestra visión del rostro. No nos hace más patente, por efecto de una amplificación o dilatación, la especificidad de este o aquel rostro. "Si implica un cambio de dimensión, -dice Deleuze- se trata de un cambio absoluto": si la imagen del rostro en primer plano tiene un poder de expresión tal, es porque manifiesta un "cambio absoluto", porque el objeto ha cambiado absolutamente ante nuestros ojos. No es, de ninguna manera, el objeto -el rostro- tal cual, sino uno que, en palabras de Deleuze, ha perdido su movimiento natural, habitual, específico, para ganar movimiento de expresión.

Si esto es así, tendremos que advertir, con Didi-Huberman, lo siguiente: "Hay que tomar nota del valor ya trastocante -en todo caso perturbador-que una problemática semejante adjudica al discurso de la 'especificidad', [el objeto] queda desestabilizado en su evidencia visible como objeto geométrico"16 o como objeto fisonómico. "Queda desestabilizado": el objeto ha dejado de 
ser concretamente lo que es, se ha producido un cambio al interior de él. La imagen -no otra cosa- nos hace patente ese cambio. El problema puede plantearse de la siguiente manera: ipuede la imagen de un rostro ser solamente la imagen de un rostro, nada más que la imagen de un rostro? Hemos de contestar, con Deleuze y con Didi-Huberman, que no. Pero, entonces, podemos preguntarnos con Didi-Huberman: “icómo juzgar una inversión semejante, un pasaje semejante a la cualidad o poder, vale decir, un tal pasaje a la interioridad?"17. Con esta pregunta en mente, pasemos ahora a hablar en positivo para explicar este pasaje a la interioridad.

\section{§ 4. La imagen-afección de Gilles Deleuze ${ }^{18}$}

“No hay primer plano de rostro, el rostro es en sí mismo primer plano, el primer plano es por sí mismo rostro, y ambos son el afecto, la imagen-afección”.

Gilles Deleuze

Delezue le da un nombre propio al primer plano: lo llama imagen-afección. Sabemos ya algunas cosas respecto de la concepción deleuziana del primer plano: el primer plano se define por su capacidad de expresar el afecto; lo logra en tanto que abstrae el rostro de sus coordenadas espacio-temporales, de sus movimientos naturales, de su especificidad; de modo tal, que el rostro en primer plano se anula a sí mismo, abriéndonos una nueva dimensión que no es ni figurativa ni trascendente. Es la dimensión del afecto. El primer plano es, pues, una imagen afectiva (ofrece "una lectura afectiva de todo el film"19). Precisemos, al respecto, tres cuestiones centrales que nos permitirán terminar de delinear esta exposición.

(a) Deleuze toma de Henri Bergson la definición de afecto: "La definición bergsoniana del afecto destacaba exactamente estas dos características: una tendencia motriz sobre un nervio sensible. En otros términos, una serie de

17 Ibid., pp. 39-40.

18 Nos basaremos principalmente en el capítulo 6 (“La imagen-afección: rostro y primer plano") y en el capítulo 7 (“La imagen-afección: cualidades, potencias, espacios cualesquiera”) de: Deleuze, Gilles, op. cit., pp. I3I-I77.

19 Ibid., p. I3I. 
micromovimientos sobre una placa nerviosa inmovilizada" ${ }^{20}$. La idea que está detrás es una que ya conocemos: el rostro ha perdido su movilidad habitual de extensión (de allí que haya pasado a ser placa nerviosa inmovilizada o, como dirá Deleuze a continuación: superficie reflejante) para pasar a ser expresión de micromivimientos. $Y$ Deleuze agrega: micromovimientos intensivos (en contraste con la movilidad extensiva). Y, poco más adelante, precisa: "cada vez que descubramos en una cosa estos dos polos, superficie reflejante $y$ micromovimientos intensivos, podremos decir: esa cosa fue tratada como un rostro (...) y ella nos clava la vista, nos observa (...)”21. Primera cuestión, entonces: la imagen se inmoviliza (pierde movimiento extensivo, deja de ser movimiento de traslación) para ganar movimiento de otro tipo: movimiento intensivo. No es, en absoluto, que la imagen se vuelva estática, sino que se mueve de una manera no habitual, de una manera intensiva. Fulgura. Cuando encontremos esta constelación en una imagen, estaremos enfrentando una imagen en primer plano o una imagen-afección ${ }^{22}$.

(b) Hay un aspecto principal que me interesa resaltar de esta definición. Se trata de la determinación del afecto (en Bergson), y por tanto, del rostro como primer plano (en Deleuze), como enmarcado, siempre, entre dos polos. Independientemente de cómo llamemos a esos dos polos (aunque los nombres que coloca Deleuze son poco menos que casuales), la idea central aquí es que el primer plano se juega en este entre dos: aquella "inmovilidad" que la imagen en primer plano captura, se compensa por una movilidad de otro tipo; Deleuze dice: "micromovilidad intensiva". Ambos polos constituyen el afecto y la imagen en primer plano y es eso lo que confiere a la imagen la latencia o vibración. Hablamos, pues, de una imagen, pero que posee esta característica especial. Segunda cuestión: de ahí que diga Deleuze: "más que de un origen

\section{Ibid., p. 132.}

21 lbid.

22 Alrededor del minuto 39 de la película que nos ocupa, tenemos un ejemplo de lo que decimos aquí: Juana está siendo preparada para la tortura y tres hombres aprovechan el momento para fastidiarla y burlarse de ella. Vemos, aquí, una serie de movimientos extensivos, habituales, por parte de los hombres: se ríen, la molestan con una paja que introducen en su oído. Pero vemos también a Juana abstraída. Soporta las burlas pero no sabemos cómo va a reaccionar; su rostro está como suspendido... casi no reacciona. La imagen coloca al rostro de Juana en una dimensión diferente de la de los hombres, que siguen con sus movimientos habituales. El rostro está abstraído, pero no por ello está detenido. Hay otro tipo de movimiento aquí: precisamente, el movimiento intensivo del que nos habla Deleuze. 
exclusivo, se trata de dos polos"23. El afecto, y con él la imagen-afección, se juega entre ambos: la imagen pierde cierta movilidad, pero gana con ello un poder de expresión capaz de hacernos penetrar en una órbita distinta.

(c) Entonces: el primer plano (esta "inmovilidad/micromovilidad") se logra, según Deleuze, por efecto de abstraer el rostro de sus coordenadas espaciotemporales. Cuando esto ocurre, cuando se abstrae así el rostro (o cualquier objeto rostrificado) y la imagen gana movimiento intensivo, no estamos ante un simple cambio de aspecto, sino, como dijo Deleuze anteriormente, estamos ante un "cambio absoluto de dimensión". La idea que tiene aquí Deleuze, me parece, es que al abstraer el rostro de este modo se genera algo nuevo, el objeto cambia de naturaleza, y de ahí que haya un cambio absoluto. Al abstraerse el rostro de sus determinaciones espacio-temporales, el rostro deja de ser lo que es, se vuelve una entidad de tipo distinto. Para explicar brevemente esto, citaré en extenso a Deleuze a la vez que intercalo el análisis; dice Deleuze: "lo que compromete la integridad del primer plano es la idea de que éste nos presenta un objeto parcial, separado de un conjunto o arrancado a un conjunto del que formaría parte. (...) Cuando los críticos aceptan la idea del objeto parcial, ven en el primer plano la marca de un despedazamiento o de un corte, y unos dicen que es preciso conciliarlo con la continuidad del film, y otros que ese corte atestigua, por el contrario, una discontinuidad fílmica esencial”. Para utilizar nuestro propio ejemplo, es como si dijéramos: no veo el rostro de Juana en primer plano, veo una parte del rostro de Juana en primer plano; yo contemplo la imagen pero completando la parte del rostro que no ha sido enfocada, unificando el pedazo de rostro con la integridad del rostro. Pero en realidad no ocurre nada de eso, "el primer plano, el rostro-primer plano, no tiene nada que ver con un objeto parcial. (...) el primer plano no arranca su objeto a un conjunto del que formaría parte, del que sería una parte, sino que, $y$ esto es completamente distinto, lo abstrae de todas sus coordenadas espacio-temporales, es decir, lo eleva al estado de Entidad. El primer plano no es una amplificación; si implica un cambio de dimensión, se trata de un cambio absoluto. Mutación del movimiento, que cesa de ser de traslación para volverse expresión. (...) Frente a un rostro aislado, no percibimos el espacio. Nuestra sensación del espacio está abolida. Ante nosotros se abre una dimensión de 
otro orden"24. Mutación implica, pues, un cambio radical. El rostro ha mutado: se ha convertido en lugar de expresión del afecto y, con ello, nosotros hemos entrado en esa dimensión ${ }^{25}$. La imagen tiene esa potencia: de abrirnos a una dimensión distinta de la dimensión habitual de las cosas físicas. Nos introduce, pues, en un ámbito donde las cosas no ocurren según el orden físico. La imagen en primer plano nos introduce directamente en esa dimensión.

En ella, las relaciones se rigen más bien por criterios de otro tipo. Es la dimensión de la potencialidad o, en palabras de Deleuze: "lugar de lo posible". No vemos la imagen en primer plano del rostro de Juana como concatenado con estado de cosas. $O$, independientemente de que lo hagamos, la imagen misma se confunde con el afecto expresado en él. En ese momento preciso, cuando nos confrontamos con la imagen de Juana, al menos por un instante la dimensión espacial ha sido abolida... estamos enganchados no con un estado de cosas que se sucede, sino con una dimensión más profunda, expectante, vibrante... cualquier cosa puede pasar. $Y$ es que "Los afectos [dice Deleuze] no tienen la individuación de los personajes y de las cosas (...). Son como puntos de fusión, de ebullición, de condensación, de coagulación" ${ }^{26}$. Es en este sentido que el rostro, imagen-afección por excelencia, pierde sus funciones características, individuantes, se anula a sí mismo como objeto espacial, para poder ser lugar de expresión de lo posible: por un momento, estamos suspendidos en un abismo de profundidades enormes.

\section{§ 5. Detrás de cámaras}

Las imágenes del rostro de Juana de Arco nos clavan la mirada. Sus miradas, aunque no se dirijan a nosotros (ia quién, a dónde se dirigen?) nos sobrecogen: el rostro no es una imagen más que transcurra en una secuencia espacio temporal, sino que es una imagen que, de algún modo, se desfasa, se abstrae de la sucesión en la que es presentada. Esto, en esta película, ha sido logrado gracias a la técnica del primer plano. Entonces, habiendo desarrollado el tema en detalle con Deleuze, me gustaría, para terminar, leer ahora nuevamente a

24 Ibid., p. 142.

25 Cf. ibid., p. 144.

21826 lbid., p. 152. 
Dreyer y articular todo este contenido con la propuesta propia del director de La pasión de Juana de Arco.

En un texto de 1955, Dreyer se pregunta: "Y llegamos ahora a la cuestión esencial: icómo se puede realizar una renovación artística en el cine?”. La pregunta se la plantea Dreyer como director, es decir, al interior de la producción artística cinematográfica misma, y contesta lo siguiente: "No puedo responder más que por mí mismo, y no alcanzo a ver más que un medio: la abstracción. Para hacerme entender diré que la abstracción es algo que exige del artista que sepa abstraerse de la realidad, para reforzar el contenido espiritual de su obra”. La abstracción aparece aquí como una exigencia del artista. Es decir, si el cine quiere ser arte, si va a aportar imágenes artísticas, la abstracción es una condición del artista (del director). Como vimos, no basta la reproducción, no basta con el aparato: el contenido espiritual, aquello que en otro momento Dreyer llamó "el alma del cine", pasa por el lado del trabajo del artista. E insiste Dreyer en que es una abstracción de la realidad: hay que abstraer o salirse de las coordenadas (espacio-temporales, extensivas, cronológicas, causales, etc.) en que parece estar fijada la realidad. Para precisar, continúa señalando: "Así pues, el cine tiene que trabajar para alejarse del arte puramente imitativo. El realizador ambicioso debe buscar una realidad más elevada que aquella que se encuentra cuando fija la cámara para fotografiar simplemente la realidad. Sus imágenes no deben ser sólo visuales, sino espirituales" ${ }^{27}$. Leo estas oraciones en el sentido de que se abre aquí una distancia entre la realidad efectiva y la "realidad más elevada" (algo que está más allá, una dimensión de otro tipo). Es precisamente en ese lugar, en esa apertura, donde se ubica el artista (el artista que debe buscar). El "contenido espiritual" emerge de esa distancia en que está instalado el artista, de la elaboración que haga el artista con esa distancia. Las imágenes de Dreyer en La pasión de Juana de Arco son imágenes inquietantes porque ellas son sostenidas por la distancia que acabo de señalar. Dreyer es, además, preciso en decir que estas imágenes no son solo visuales, sino también "espirituales". El solo aquí es importe: son visuales, pero no son solo visuales. Esto puede ser reforzado con otro testimonio de Dreyer, que nos permite, además, reconectar el asunto con el tema de la vibración propia

27 Dreyer, Carl Theodor, op. cit., pp. 90-91; cursivas añadidas. Este texto corresponde a una conferencia que dio Dreyer el día anterior a la inauguración del festival de cine de Edimburgo en 1955. 
de La pasión de Juana de Arco. De esta película, Dreyer alguna vez dijo: "me dio justo lo que representa mi voluntad, mi sentimiento, mi pensamiento: mística realizada" ${ }^{28}$. Pareciera aquí decir algo así como que las imágenes de La pasión de Juana de Arco "dieron justo en el blanco: aquello que estaba buscando, la película lo encarnó”. Dreyer se sirvió del personaje histórico de Juana de Arco, pero para regalarnos algo más que la historia de Juana de Arco: para regalarnos, en sus palabras, "mística realizada".

De ahí, entonces, que Dreyer concluya: "La tarea del director de cine consiste en que los espectadores compartan sus propias experiencias artísticas o interiores. La abstracción le ofrece la oportunidad de hacerlo ya que, gracias a ella, sustituye la verdad objetiva por su propia interpretación subjetiva" ${ }^{29}$. Los espectadores podrán ser interpelados, inquietados por un buen director, en la medida en que este cumpla con su tarea: ofrecer imágenes auténticas que nos revelen perspectivas y dimensiones insólitas (más profundas) a partir de las cuales contemplar los diversos aspectos de la realidad. Solo así, a través de la abstracción (esta exigencia interior y trabajo propios del artista), se producirá en ellos un desvío de lo objetivo (orden de la evidencia, del dato) a lo afectivo (orden de lo subjetivo, de la experiencia).

He utilizado aquí la palabra desvío arbitrariamente porque quiero ahora, para cerrar, volver a un último comentario de Deleuze sobre la película que estamos analizando. Refiriéndose a La pasión de Juana de Arco, Deleuze dice: "Extraordinario documento sobre el giro y el desvío de los rostros. Estos cuadros fragmentados responden a la noción de 'espacios fuera de cuadro', propuesta (...) para designar ángulos insólitos que no se justifican completamente por las exigencias de la acción o de la percepción"30. "Es como un cortocircuito de lo cercano y lo lejano" que instaura "el desvío del o de los rostros, que abre y describe ese espacio. (...) Por el giro-desvío el rostro expresa el afecto"31. Llama la atención la expresión "cortocircuito de lo cercano y lo lejano", aquel juego que desvía de la percepción del rostro a la expresión del afecto. ¿Acaso no podemos decir que ocurre exactamente esto al contemplar el rostro de Juana

28 Ibid., p. 40. Extracto de "La mística realizada" (Politiken, 19 de noviembre de 1933).

29 Ibid., p. 9l. Extracto de la conferencia para el festival de cine de Edimburgo (1955).

30 Deleuze, Gilles, op. cit., p. 157.

22031 lbid., pp. I53-I54. 
de Arco? Su rostro está allí en la pantalla, frente, cerca a nosotros, expuesto además con íntimo detalle. No obstante, su presencia nos hace prácticamente rebotar hacia otro lado (¿dónde?, difícil de explicar). Su presencia nos aferra pero a la vez nos expulsa. Y allí, en ese frágil lugar, nos ubicamos nosotros. Tal como señala Didi-Huberman: "Entonces empezamos a comprender que cada cosa por ver, por más quieta, por más neutra que sea su apariencia”, como el rostro de Juana de Arco en el fragmento de la película descrito al inicio de este texto, "se vuelve ineluctable cuando la sostiene una pérdida (...) y, desde allí, nos mira, nos concierne, nos asedia"32. Curiosa, extraña e inquietante coincidencia entre este evento particular y las palabras de Didi-Huberman. Motivo suficiente para hacerle caso también en esto último: "Abramos los ojos para experimentar lo que no vemos (...). Todo está alli’”33.

32 Didi-Huberman, Georges, op. cit., p. 16.

33 Ibid., p. 17. 